FOLIA SCANDINAVICA

VOL. 27 POZNAŃ 2019

DOI: $10.2478 /$ fsp-2019-0004

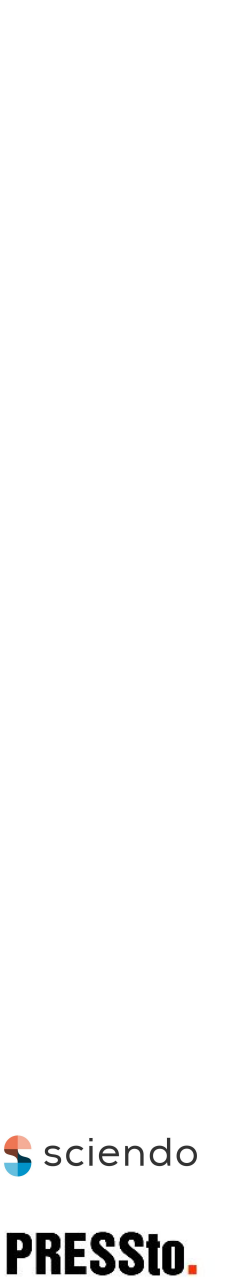

\title{
LINGUISTICS
}

\section{DET AMBIVALENTE KVINDEBILLEDE I DANSKE ORDSPROG}

\author{
TOMASZ ARCHUTOWSKI
}

University of Gdańsk

\begin{abstract}
The aim of the paper is to identify the image of a woman coded in Danish proverbs. The basis of my research is the assumption that proverbs convey knowledge of how societies perceive the reality and that proverbs are used as interpretative mechanisms. This is mainly achieved thanks to the repetitive nature of proverbs. Simultaneously proverbs force certain perception of the world upon societies and promote certain values.

The image of a woman in the Danish language is composed by two stereotypes, a negative and a positive one. The image is a combination of contradictions. On one hand there is admiration for features such as care, motherhood, life experience and, hard work, but on the other hand women are submitted to discrimination and harsh social pressure. Women are depicted as talkative, dominating, evil, vain, unpredictable, unrestrained. They face pressure to get married, take good care of their looks, or be exemplary housewives. The analysis of Danish proverbs gives a possibility to observe how much women's social status, character and the perception of women by the society have changed throughout the centuries and how these changes have influenced the language we use and the reality that the language depicts.
\end{abstract}

\section{INDLEDNING}

Formålet med denne artikel er at analysere, hvilken opfattelse og hvilket billede af kvinden der bliver formidlet af danske ordsprog. Udgangspunktet for min analyse er, at ordsprog formidler viden om, hvordan forskellige befolkninger betragter verden, og at ordsprog bliver brugt som redskaber til at fortolke virkeligheden. Ordsprog påtvinger også et bestemt virkelighedsbillede og promoverer bestemte værdier. 


\section{ORDSPROGS OPRINDELSE, DEFINITION OG KARAKTERISTIKA}

Hvad er et ordsprog? Hvad er dets oprindelse? Ordsprog har eksisteret i forskellige sprog $i$ århundreder. Den ældste danske ordsprogssamling stammer formentlig fra 1300-tallet. Den blev nedskrevet af Peder Laale og for første gang trykt i 1506. Samlingen indeholdt ca. 1200 ordsprog på latin og dansk og blev gennem 200 år anvendt som lærebog i danske skoler. Den blev brugt til indlæring af gloser, grammatiske konstruktioner og til øvelser i metrik. En vigtig kilde til ordsprog har været Bibelen, og mange af de ordsprog, som har deres oprindelse i Bibelen, bliver brugt i dag. Det er en kompliceret opgave at forklare ordsprogs oprindelse, men mange ordsprog kan placeres i en bestemt historisk kontekst, da de f.eks. afbilder sociale, økonomiske og kulturelle forhold i landsbysamfundet. Det antages, at ordsprog først er blevet formuleret af en veloplyst, lærd person, og så er de blevet viderebragt og udbredt gennem folket (Hoffman 2013).

Det er problematisk at definere ordsprog, da de ofte forbindes med andre fagområder som litteratur, kulturformidling, lingvistik og sociologi, hvilket har ført til forskelligartede definitioner af begrebet.

Politikens Nudansk Ordbog angiver følgende definition af et ordsprog: "fast sproglig vending, der kort sammenfatter en erfaring eller leveregel, ofte i billedlig form" (Nudansk Ordbog 2005)

I. Kjær definerer et ordsprog på følgende måde: "Ved et ordsprog forstås en udbredt anonym sætning, som har fast og prægnant, ofte billedlig, form, og som med tilsyneladende almen gyldighed udtrykker en bestemt forklaring eller vurdering af en given menneskelig situation" (Kjær 1993:11).

N.F.S. Grundtvig definerer i sin afhandling "Om ordsprog" begrebet som: "enhver kort, almindelig sætning af flere eller færre led, hvorpå der i folkemunde er sat stempel, så den går for rede penge" (her citeret efter Ravn (2017)).

Ordsprog har en bestemt stil og form, som Kjær og Holbæk beskriver således:

I. De udtrykker indsigt, erfaring eller anskuelse af almen art.

II. De overleveres mundtligt, hvorfor de må være lette at huske (Kjær/ Holbæk 1989:21 ff.).

Derefter supplerer Kjær \& Holbek punkt I med følgende detaljer:

1. Ordforrådet er enkelt, alment, gammelt, umiddelbart forståeligt.

2. Ordsprogenes begrebsverden og billed- og symbolsprog er af helt almen art.

3. Syntaksen (sætningsbygningen) er enkel.

4. Meninger udtrykker [-s] ligefremt og kategorisk.

5. Verbet er oftest i præsens (nutid), evt. imperativ (bydeform), eller det mangler. 
6. Substantiver optræder ofte artikelløst, undertiden i ubestemt form.

7. Negation (nægtelse) anvendes ofte til at gøre udsagnene almene og ubestemte.

8. Regler fremgået af umiddelbar iagttagelse fremsættes i almen form og overføres metaforisk på andre områder.

Punkt II udvider Kjær og Holbek med følgende punkter:

1. metafor

2. rytme

3. bogstavrim

4. enderim

5. modsætning og parallelitet etc.

Disse forhold gør ifølge Kjær og Holbek ordsprogene lette at huske (Kjær/Holbæk 1989:29 ff.).

O. Kragh nævner følgende træk ved et ordsprog: billedlig tale, korthed, rytme, rim, ordspil og parallelisering (Kragh 2017).

Der findes en række ord, som betydningsmæssigt ligger i nærheden af ordet ordsprog som f.eks. mundheld, bevinget ord, bonmot, aforisme, epigram, citat, fyndord, frase, gruk, guldkorn, talemåde. På trods af visse syntaktiske og semantiske forskelle mellem ovennævnte begreber, udviser de alligevel langt flere ligheder, og derfor kan de betragtes som former, som er beslægtet med hinanden, og som har deres oprindelse i ordsprog (jf. Skuza 2012:9).

Der findes forskellige måder at kategorisere ordsprog på. Inden for dansk forskning i ordsprog skelner man tit mellem:

1. Metaforiske ordsprog, som f.eks. AEblet falder ikke langt fra stammen

2. Ordsprog med bogstavelig betydning, der typisk indeholder forskrifter for, hvordan mennesker bør handle af moralske og praktiske grunde.

3. Wellerismerne eller skæmtesprogene er ordsprog opkaldt efter en figur hos Charles Dickens, Pickwicks tjener, Sam Weller, som bruger mange af den slags skæmtesprog. Ole Kragh (2017) definerer wellerismerne som "ordsprog, som har en bestemt grammatisk form, der består af et udsagn, f.eks. et citat eller et ordsprog, efterfulgt af udtrykket 'sagde han', 'sagde konen', 'sagde kællingen' etc., og en eftersætning, der giver ordsproget eller citatet en komisk belysning, gennem modsætningen mellem den specielle situation og de anførte ord." (Kragh 2017:10).

K. Kristiansen skelner mellem fire grupper ordsprog, nemlig:

1. Egentlige ordsprog, dvs. faste, anonyme vendinger, der udgør hele sætninger (f.eks. Man kender trceet på dets frugter). 
2. Ordsprogsagtige talemåder og sammenligninger, der udgør led i sætninger (f.eks. Han saae ud, som om han havde, efter Ordsproget, brondt Falster af og vilde flye over til Laaland).

3. Mundheld, skæmtesprog og wellerismer (f.eks. Intet er så styrkende som en ordentlig søvn. Det sagde tjenestepigen også, før hun tømte bageret med opium).

4. Bonde- og vejrregler (f.eks. Aaret begynder med Januar; Dagen er kort, og Marken bar) (jf. Kristiansen 2012:7).

H.V. Rasmussen deler til gengæld ordsprog op i tre kategorier:

1. Egentlige ordsprog (f.eks. Det er sødt at drikke og surt at betale).

2. Skæmtesprog (f.eks. Damerne først, sa'e Matrosen, der skulde nogen kastes over Bord).

3. Bondesprog (Landbrugsregler) (f.eks. Ros ikke Byggen i Blade, før du har den i Lade). (Rassmusen 1920:4 ff.)

Ordsprog er vendinger, som er baseret på klicheer og gentagelser. Gennem deres repetitive natur bekræfter de bestemte egenskaber ved ting, fænomener og personer, og på den måde bekræfter og fastholder de stereotyper. Ordsprog fastholder menneskets viden om verden samt hjælper mennesket med at fortolke virkeligheden.

\section{STEREOTYPER SOM INFORMATIONSKILDE OM VÆRDIER OG KULTURELLE ADFÆRDSMØNSTRE}

Stereotyper er en del af det sproglige verdensbillede og en informationskilde om værdier og kulturelle adfærdsmønstre, der karakteriserer et samfund (Piętkowa, 2007:97).

Det sproglige verdensbillede er et begreb, hvis oprindelse kan spores tilbage til Wilhelm von Humboldt og hans efterkommer Leo Weisgerber samt de amerikanske sprogforskere Benjamin Lee Whorf og Edward Sapir. Men de første teorier angående sprogets påvirkning på menneskets verdensanskuelse er endnu ældre. De forekommer nemlig i Aristoteles' Retorik (Bock: 1992:248). Jerzy Bartmiński påpeger, at Aristoteles skrev om loci communes, dvs. om alment udbredte, kendte, repetitive holdninger, som påvirker vores tankegang og overbevisningsproces (Bartmiński 2001:28 f.). Om forbindelsen mellem menneskets tankegang og sproget skrev også Martin Luter og de tyske filosofer Johan David Michaelis, Johan Georg Hamann og teologen og litteraturkritikeren Gottfried Herder. Visse elementer af det sproglige verdensbillede kan tillige spores i Ludwik Wittgensteins og Hilary Putmans værker.

En stereotype er en fastholdt bedømmelse, der tilskrives et bestemt begreb. Ifølge typisk dikotomisk kønsopfattelse vil "kvindelig intuition" blive bedømt 
som noget negativt af mænd. Jann Scheuer (1998:97) skriver det følgende den dikotomiske kønsopfattelse:

Megen tænkning i køn tager udgangspunkt i en stereotyp dikotomisk kønsopfattelse. Man søger at vise at kvinder er på en måde og mænd er på en anden måde. Kønnet opfattes som en kategori, der har to værdier: mand eller kvinde, og til de to værdier knyttes to fundamentalt forskellige væremåder, tænkemåder, handlemåder, eller hvilke måder diskussionerne nu søger at forholde sig til. Den biologiske dikotomi føres direkte over i en social og psykologisk dikotomi, og det er til skade for forståelsen af køn som social og psykologisk dannelse. Resultatet bliver en naiv og forsimplende forståelse, som ofte kan medvirke til at fastholde stivheden i den herskende kønsopfattelse i stedet for at opløse den.

Intuition tilskrives typisk kvinder, da det antages, at emotioner og følelser er iboende kvindelige egenskaber, mens logisk tænkning anses for at være mere typisk for mænd.

Mennesket og den måde, mennesket ser verden på, spiller en central rolle i forskning $\mathrm{i}$ det sproglige verdensbillede, men forskningen $\mathrm{i}$ det sproglige verdensbillede indebærer også, at der må tages hensyn til en meget karakteristisk egenskab ved mennesket, nemlig bedømmelse/vurdering. Vurderingen er et nøglebegreb i forbindelse med undersøgelse af det sproglige verdensbillede. Den vurdering, som vi udtrykker gennem sproget, kan være positiv, negativ, men vi kan også være ligeglade over for bestemte adfærdsmønstre. På denne måde er sproget et redskab til at fortolke virkeligheden. Det sproglige verdensbillede dannes ikke kun på baggrund af sproget, men også på baggrund af forskellige kulturelle og sociale forhold.

Stereotyper er en del af det sproglige verdensbillede, men de er også en uundværlig informationskilde til den måde, vi bedømmer forskellige begreber på, og om de gældende adfærdsmønstre i den bestemte kultur. Stereotyper er et kulturprodukt, men også et vigtigt element, der er med til at danne kultur (jf. Wysoczański 2006:84).

Jerzy Bartmiński påstår, at det sproglige verdensbillede er menneskets holdninger til verden. Det kan være holdninger, der er fastholdt i selve sproget, altså f.eks. i grammatik, ordforråd, ordsprog eller holdninger, som bliver formidlet gennem sprogets former og tekster (jf. Bartmiński 2012:12).

Ifølge J. Puzynina spiller aksiologi en absolut afgørende rolle ved fortolkningen af det sproglige verdensbillede. Næsten hvert ord, vi bruger, formidler/udtrykker bestemte følelser, værdier, bedømmelser, vurderinger. Ved at lære disse følelser, værdier og holdninger at kende, bliver vores generelle viden om mennesket større. Desuden kan vi bruge disse holdninger i konfliktsituationer eller til at bedømme andre menneskers intentioner (jf. Puzynina 1992:83). 


\section{DET SPROGLIGE BILLEDE AF KVINDEN I DE DANSKE ORDSPROG}

For at finde frem til det sproglige billede af kvinden i de danske ordsprog har jeg undersøgt ca. 2500 ordsprog, som jeg har fundet i de mest omfattende, danske ordsprogssamlinger af forfattere som: Peder Syv (jf. Hansen 1944), N.F.S. Grundtvig (jf. Ravn 2017), Evald Tang Kristensen (1890) og Kristian Kristiansen (2012). Af de undersøgte ordsprog refererer ca. 100 til kvinden. I de undersøgte ordsprog forekommer forskellige synonymer og eventuelt andre betegnelser for ordet kvinde så som: kælling, kone, pige, moder, frøken, frue, mø, jomfru, moder, skøge (prostitueret), ludder, datter, brud, fruentimmer (dvs. prostitueret). En stor del af de ordsprog, jeg har undersøgt, indeholder ordet kælling, som semantisk har en negativ værdiladning. En kælling er typisk gammel, grim, ondskabsfuld, snakkesalig, uintelligent, klodset. Kællingen bliver tit sammenstillet med fanden, djævlen. En kælling bliver hånet for sin latter, sin stemme, sit udseende: Fandens bedste ildtang er en ond kolling; Tandløs kaelling boer' nid ved at andre fär mad; Det er ikke Børne-Vark, naar gammel Kicelling dandser; Borte er borte, sagde Kallingen om sit Øre; Kicellinge-Latter bliver let til Hoste; Der er langt frem, sagde Kicellingen, hun saae sig tilbage;

Som allerede nævnt før, er et karakteristisk træk ved ordsprog og mundheld deres repetitive natur, der spiller en afgørende rolle i dannelsen af stereotyper. På baggrund af de undersøgte ordsprog kan man konstatere, at de danske ordsprog danner følgende stereotyper om kvinder:

\begin{tabular}{|l|l|}
\hline \multicolumn{2}{|c|}{ Negative stereotyper } \\
\hline Kvinder er: & \multicolumn{1}{c|}{ Ordsprog } \\
\hline løgnagtige, snu & $\begin{array}{l}\text { Man skal have sandhed at vide af børnene og løgn af } \\
\text { kallingerne. Det er ikke Alle Frøkener, som } \\
\text { har favert (fagert, dejligt) Haar. }\end{array}$ \\
\hline $\begin{array}{l}\text { bestikkelige, } \\
\text { pengekære }\end{array}$ & $\begin{array}{l}\text { Man fanger Kvinder med Gods, Narre med Roes og Harer } \\
\text { med Hunde. }\end{array}$ \\
\hline stridige, trodsige & Faare-Skrcek og Kvinde-Vrede endes gierne med Voede. \\
\hline snakkesalige & $\begin{array}{l}\text { Høirøstede Kvinder skal man bruge til at forjage } \\
\text { Krigshøre med; Der skal et stort plaster til at doekke } \\
\text { munden på en gal kalling; Hvor én sladderkcelling er, } \\
\text { kommer snart flere; Kvinder borer svordet på tungen, så } \\
\text { det er ikke vord at klappe på skeden. }\end{array}$ \\
\hline grådige & $\begin{array}{l}\text { Kvinde og Mølle fattes (mangler) altid noget; Kvinde, } \\
\text { mølle og skib fattes altid noget. }\end{array}$ \\
\hline dominerende & $\begin{array}{l}\text { Did kommer Kage, som Kone vil; Koste hvad koste vil } \\
\text { (sagde Konen, jeg vil have min Villie). }\end{array}$ \\
\hline onde & $\begin{array}{l}\text { Onde kvinder og skabede får, de mangler ikke mens } \\
\text { verden står, En ond Kvinde er Helvedes Dør-Navle; }\end{array}$ \\
\hline
\end{tabular}




\begin{tabular}{|l|l|}
\hline & $\begin{array}{l}\text { En ond Mand er som en Djeevel, og en ond Kvinde som et } \\
\text { heelt Helved., }\end{array}$ \\
\hline stædige & $\begin{array}{l}\text { En Mand er en Mand, et Ord er et Ord (og en Kicelling er } \\
\text { en Kicelling. }\end{array}$ \\
\hline forfængelige, griske & Mens Gaver gives, er Moder og Datter vene (venlige)- \\
\hline $\begin{array}{l}\text { uberegnelige, } \\
\text { uforudsigelige og } \\
\text { luskede }\end{array}$ & $\begin{array}{l}\text { Man maa kiende den Kone, hvis Pølse man spiser; Tre ting } \\
\text { skal man ej rose for tidligt, byg i blade, føle i stade og } \\
\text { kvinde i gade; Det er lettere at passe pà en scek lopper end } \\
\text { på en kvinde; Manden vidste ikke hans Kone var gal, før } \\
\text { hun sang over Borde, }\end{array}$ \\
\hline Mandvoksen mø er ond at vogte. \\
\hline $\begin{array}{l}\text { løsslupne } \\
\text { opfattes som generel } \\
\text { trussel }\end{array}$ & $\begin{array}{l}\text { Kvinder, ild og vand truer på livet hver en mand. } \\
\text { Mands list er vel behcende, men kvindelist er uden ende. }\end{array}$ \\
\hline magtsyge & Kvindevceld har intet hoeld. \\
\hline flygtige & Kvinder har korte sind under lange klceder. \\
\hline
\end{tabular}

Samtidig bliver kvinden underlagt et stort pres, og ordsprogene afspejler et feudalt, middelalderligt og religiøst bestemt verdensbillede, hvor kvinden er underlagt manden. Kvinden må være ung og smuk: Hellere tage en pige $i$ hendes ene sark (undertrøje) end en enke med alt hendes skrammelvaerk. Men samtidig må kvinden ikke være for smuk, for: Hvor der haver en fager (dejlig) kvinde og en hvid hest, er sjoeldent uden bekymring. Kvinden bør være kvik, intelligent: Brogeløs Mand og raadløs Kvinde duer ikke stort, flittig: En staaende Sypige og en siddende Kokkepige duer kun lidt. En eftertragtet kvindetype er en jomfru: Eet Jomfru-Haar kan trcekke meer end ti Par Heste. Kvinder, der drikker, får en negativ omtale i danske ordsprog: Det kvoelder ei, hvor Kvinder drikke. Kvinder er ifølge de danske ordsprog jaloux: Så ncer var jeg ved det, sagde pigen, da den der sad hende noermest blev budt op til dans. Kvinder skal helst være dydige: Kåde (lystfulde) pige er farligt gods $i$ gemme at holde lange. I de danske ordsprog lægges vægt på renlighed (både fysisk og moralsk): Aske-Brud (uren) bliver aldrig kirkeprud (smykket til kirkegang). De danske ordsprog giver også advarsler til mænd, der kommer i kontakt med kvinder: Der er kun lidt givet $i$ hvad fattig Kone spinder for.

En del af de undersøgte ordsprog har vist sig at danne et positivt billede af kvinden ved at fremhæve følgende karaktertræk:

\begin{tabular}{|l|l|}
\hline \multicolumn{2}{|c|}{ Positive træk ved kvinden } \\
\hline \multicolumn{2}{|c|}{ Ordsprog } \\
\hline Omsorg, moderskab & $\begin{array}{l}\text { Hvo Barnet tager ved Haand, tager Moderen om Hjertet. } \\
\text { Hvem kiender en Moders Hjerte! }\end{array}$ \\
\hline kvindens livserfaring & Bedre er gammel Mø end ung Skiøge \\
\hline $\begin{array}{l}\text { kloghed, fornuft og } \\
\text { flid }\end{array}$ & $\begin{array}{l}\text { En klog Mand giør en viis Kone, og en klog Kone giør en } \\
\text { lykkelig Mand. }\end{array}$ \\
\hline
\end{tabular}


Kvinden spiller en socialt vigtig rolle, er med til at opretholde/opbygge den enkelte husholdnings sociale status: Som Konen, saa Huset. Ordsprog fremhæver kvindens store betydning i mandens liv. Kone-Død er Albu-stød (stærk smerte, sorg).

\section{KONKLUSION}

De danske ordsprog giver et broget billede af kvinden. Det er et billede, der er fuldt af modsigelser. Det er et billede, der er en blanding af beundring for sådanne egenskaber som omsorg, moderskab, livserfaring og flid. Beundringen for netop disse egenskaber kan forklares ved, at de afspejler de helt grundlæggende forestillinger og forventninger i forhold til kvinden, der fungerer $\mathrm{i}$ vores kultur. Men samtidig får vi et billede af en kvinde, der er udsat for diskrimination, hån og et voldsomt socialt pres. Kvinder fremstilles som snakkesalige, grådige, dominerende, onde, forfængelige, uforudsigelige og løsslupne. En analyse af ordsprogenes kvindebilleder giver mulighed for at iagttage, hvordan kvindens rolle, karakter, væremåde og image i samfundet har været $\mathrm{i}$ en bestemt historisk periode og dermed hvilke ændringer der er sket i forhold til nutidens kvindebillede og hvordan de ændringer har sat sit præg på sproget, der afbilder den virkelighed, vi lever i. Selv om mange af de stereotyper, som bliver formidlet ved de danske ordsprog, ikke længere er aktuelle i det moderne, danske samfund, hvor kønsligestilling og kvinders frigørelse er blevet nøglebegreber, spiller stereotyper stadig en vis rolle og påvirker kvinders stilling $\mathrm{i}$ samfundet. De mange stereotyper om kvinder, som hovedsageligt har været dannet af mænd, behøver ikke nødvendigvis opfattes som noget negativt eller nedsættende overfor kvinder. De kan blot betragtes som mandens forsøg på at forstå det ukendte, det anderledes. Stereotyper spiller en væsentlig rolle i den sproglige kommunikation. Stereotyper er faste og uundgåelige sproglige fænomener, som medvirker til at verbalisere bestemte holdninger og forestillinger og de udgør "een af det naturlige sprogs egenskaber" (Bartmiński/Panasiuk 1993). I daglig tale er stereotyper negativt ladede, og de betegner noget, der er ensformigt, repetitivt og genkommende. Som sociologisk, psykologisk og lingvistisk begreb er en stereotyp dog ambivalent: den kan medvirke til udbrud af konflikter og forskellige former for vold og diskrimination, men den kan tillige udgøre en kondenseret og værdifuld måde at opnå viden om os selv og de andre, dvs. om et fragment af det sproglige verdensbillede. Stereotyper bidrager til tilegnelse af diverse oplysninger takket være forestillingsskemaer og radikale generaliseringer. Schaff (1981:36) definerer en stereotype som en form for bearbejdelse af oplysninger.

Ordsprog, der henvender sig til menneskets karakter, formilder en stereotyp, forenklet verdensbillede, der baserer på kulturelle forestillinger, fordomme, myter og forudfattede meninger, som viderebringes fra generation til generation. 
Men hvordan kan man egentlig forklare grunden til det overvejende negative kvindebillede, der forekommer i de undersøgte ordsprog? Én mulighed er, at det er religionen og kirken, der har bidraget til det. Gennem århundreder har præster i deres prædikener benyttet sig af forskellige motiver fra Biblen, hvor kvinden ofte fremstilles som en kilde til ondskab. Egenskaber som falskhed eller referencer til kvindens djævelske natur, der ofte forekommer i de undersøgte ordsprog kan have haft deres rødder i religionen. Det negative billede af kvinden i ordsprog kan også afspejle en holdning om, at kvinden repræsenterede kaos og uberegnelighed, mens manden symboliserede orden og civilisation, en holdning, som var udbredt i oldtiden og middelalderen, og som vandt stor popularitet i 1500-tallet, hvor ordsprogene blev samlet og nedskrevet (Bogucka 2006).

\section{LITTERATUR}

Bartmiński, J. (2001). O Językowym obrazie świata Polaków końca XX wieku. I: S. Dubisz., S. Gajda (red.), Polszczyzna XX wieku. Ewolucja i perspektywy rozwoju (s. 27-53). Warszawa: DW Elipsa.

(2012). Językowe podstawy obrazu świata. Lublin: Wydawnictwo Uniwersytetu Marii Skłodowskiej- Curie.

Bartmiński, J., Panasiuk J. (1993). Stereotypy Językowe. I: J. Bartmiński (red.), Wspótczesny język polski. Encyklopedia kultury polskiej XX wieku, t. II (s. 363-387). Wrocław: "Wiedza o kulturze".

Bock, P. K. (1992). World View and Language. I: W. Bright (ed.-in-chief), International Encyclopedia of Linguistics vol. 4 (p. 248-251). New York: Oxford University Press.

Bogucka, M. (2006). Gorsza pteć. Kobieta w dziejach Europy od antyku po wiek XXI. Warszawa. Hansen, A. (1944). Peter Syvs Danske Ordsprog. København: Ejner Munksgaards Forlag.

Hoffman, T. (2013). Hvordan opstår et ordsprog? Hentet fra: https://videnskab.dk/sporgvidenskaben/hvordan-opstar-et-ordsprog (14.07.2019).

Kjær, I. (1993). Gode ord er bedre end guld. Om ordsprogs art og brug. I: H. Blicher (red.), Gode ord er bedre end guld. Ordsprog i perspektiv (s. 11-17). København: Rundetårns Forlag.

Kjær, I., Holbek, B. (1989). Ordsprog i Danmark 4000 ordsprog fra skrift og tale gennem 600 år. København: Jørgen Paludans Forlag.

Kragh, O. (2017). Talemåder og ordsprog fra hele verden. København: Lindhardt og Ringhof Forlag A/S.

Kristensen, E.T. (1890). Danske ordsprog og mundheld, skjæemtsprog, stedlige talemåder, ordspil og samtaleord. Kjöbenhavn: Gyldendalske Boghandel.

Kristiansen, K. (2012). Danske Ordsprog. Rødovre: Askholms Forlag.

Piętkowa, R. (2007). Językowy obraz świata i stereotypy a nauczanie języka polskiego. I: A. Achtelik, J. Tambor (red.), Sztuka czy rzemiosto? Nauczyć Polski i polskiego (s. 85-104). Katowice: Wyd. Gnome.

Politikens Nudansk Ordborg. (2005). København: Politikens Forlagshus A/S.

Puzynina, J. (1992). Język wartości. Warszawa: PWN.

Rasmussen, H.V. (1920). Danske Ordsprog. København: G.E.C. GAD.

Ravn, K. S. (2017). Indledning til Danske Ordsprog og Mundheld, samlede og ordnede af Nik. Fred. Sev. Grundtvig. Hentet fra: http://www.xn-grundtvigsvrker-7lb.dk/tekstvisnig/ 10300/0\# $\{\% 220 \% 22: 0, \% 22 \mathrm{k} \% 22: 16, \% 22 \mathrm{v} 0 \% 22: 0\}(25.11 .2019)$.

Schaff, A. (1981). Stereotypy a działania ludzkie. Warszawa: Książka i Wiedza. 
Scheuer, J. (1998). På catwalk med 3x3 matrix. Nydanske Studier \& Almen Kommunikationsteori 24, 97-122. Hentet fra: https://www.nys.dk/article/view/13399/11406 (25.11.2019).

Skuza, S. (2012). Stereotypowy obraz kobiety w paremiach oraz frazeologii polskiej $i$ wtoskiej. Poznań: Instytut Naukowo-Wydawniczy Maiuscula Sp. z o.o.

Wysoczański, W. (2006). Językowy obraz świata w porównaniach zleksykalizowanych. Na materiale wybranych języków. Wrocław: Wydawnictwo Uniwersytetu Wrocławskiego.

\section{Tomasz Archutowski}

University of Gdańsk

Institute of Scandinavian and Finnish Studies

ul. Wita Stwosza 51

80-308 Gdańsk

Poland

tomasz.archutowski@ug.edu.pl 